\title{
Women, Fascism, Everyday Life, Conference at the Ohio State University April 28-30, 1983
}

\section{Jane Caplan}

Bryn Mawr College

This was an unusually exhilarating conference. organised by members of the German Department at OSU. but with a welcome freedom from disciplinary rigidity. Most of the 15 or so speakers came formally from academic institutions in the USA and Germany, as historians. literary theorists. psychologists and so on, but they also represented much more diverse positions and perspectives than this suggests. From the platform and from the floor people spoke deliberately as women (sometimes as men). as Germans. as leshians, as homosexuals, as members of older and younger generations, as Jews. as exiles, as combinations of these and more. The topics covered and the viewpoints expressed were thus extraordinarily diverse. Indeed. on the last day a despairing (or hopeful?) question submitted to the tinal panel referred to the wide variety of research methods that had been aired over the three days, and asked which was the one most likely to succed. I think it was an unanswerable question. at any rate at a conference which was as deliberately eclectic as this one. Work on women and gender has eroded the framework of a good many research disciplines and subiects. and there are reasons why it should be even more explosive in the case of fascism. There's the problematic legacy of Reich. for one thing. Also the sense that Vazi Germany as well as posing peculiar difficulties of explanation and interpretation. represents so many extremes of morality and experience - as if it were a kind of historical absolute zero providing special conditions for investigating a whole range of human issues. An old conventional wisdom sees it as a period when sex and gender divisions were at their most extreme and naturalised in recent history: though one of the yelds of this conference was that it questioned this wisdom, along with others. At any rate. the conference demonstrated the diversity of questions being posed to the history of Vazism and that of women, and made no attempt to provide a sunthesis. This was left to the participants: or possibly to a further event.

One might say that discourse ruled this event, without privilege. The organisers characteristically didn't title the sessions, but paired off two presentations per session. and left them to speak for themselves. Actually. I suppose there was a motion 
in the proceedings. which ran from the more collective and conventionally historical. to the final session on oral history and personal experience - though this was constantly prefigured in the autobiographical fragments which turned up throughout the discussions. Nancy Vedder-Shults and Annemarie Tröger opened the conference with. respectively, a very useful comparison of Nazi propaganda on women with some of the main policy enactments on employment, birth control, etc.; and an analysis of women's employment in the 1930s. Here the first convention fell to research, as Tröger argued forcefully that Nazi policy conformed less to the ideology of family and motherhood than to the needs of a rationalised industrial labour market with a sectoral demand for cheap, unskilled, intensively exploited labour. In the following session. George Mosse produced a characteristically eclectic account of the role of Woman in 19th-century national symbolisms, while Jost Hermand's complementary paper discussed the lineage of a bizarre stratum of Nazi matriarchal theorists. The final speaker on the first day was Hildegard Brenner, who questioned tendencies in the current West German women's movement to bury the specificity of Nazism in the broader history of patriarchal oppression. Brenner raised many uncomfortable issues. including the suggestion that most women (perhaps most Germans) came to terms with the regime in an attitude of "passive consensus." Brenner thus broached for us the difficult question of what constitutes resistance, what constitutes support. (Tim Mason, in History' Workshop Journal 11. has argued for the existence of a "workers" opposition" after 1933. Incated in the persistence of economic class struggle. If this is plausible, is there a possible counterpart to it in the arena of sexual politics? Or is the latter too displaced to yield such straightforward categories?)

Day two opened with psychological interpretations. Klaus Theweleit (whose Mannerphantasien is at last being translated, by Minnesota University Press) speculated in a highly subjective way about subjectivity in history-writing. the experience of childhood and its relation to political movements, and the communicability of motive and experience. By contrast, Jessica Benjamin advanced a cautiously delimited thesis to explain Hitler's personal popularity in terms of a possible identification of him with the pre-Oedipal father. I found her care in circumscribing the explanatory power of this kind of psychology refreshing, as also her refusal to be drawn into debates about the historicity of the ego in western Europe. However, the discussion inevitably focussed on querving the usefulness of psychology to history, perhaps implying that introjection and historical explanation remain difficult to combine in a working relationship. The day concluded with James Steakley's account of the experience of homosexual men in Nazi Germany, both in NSDAP groups like the Hitler Youth and as victims of murderous persecution: an important contribution to a little understood aspect of the regime. This was paired with Atina Grossman's review of some of her research on the Weimar Republic's partly socialist sex reform movement. whose collectivism and eugenicism (in the name of social emancipation) challenge some of our current categories of opposites.

The final day took up the themes of identity and experience more personally, 
starting with Evelyn Beck's discussion of Jewish identity in the face of the history of Nazi racism. Finally, two of the German visitors, Annemarie Tröger and the author Ingeborg Drewitz, spoke of women's experience in the Third Reich: Drewitz of her own life in Germany in the 1930s and 1940s, Tröger through the Berlin oral history project with which she has long been working. Drewitz uttered one of the most telling comments of the conference, on her tutelage in the BDM (the League of German Girls): "We learned to suffer instead of to resist."

Suffering, resistance, indifference, consensus, oppression: all clearly characterised women's experience in Nazi Germany, though we did not on this occasion learn clear ways of explaining who felt what and why. Sex and gender as categories of political discourse operate in ways which are extraordinarily hard to combine with the more familiar terms in which we have tended to study history and politics. Perhaps Theweleit's unusual and extremely subjectivist approach to the problems of effective consciousness was itself an expression of the obstacles that stand in the way of explanation, whether of a person or of an event, when experience is accorded the primary authority. At a certain point in this, one threatens to lose the right to say anything authoritative as a historian or an other, and I am not sure what is then possible by way of explanation, or indeed purposeful action in the present. Solipsisms of the kind were, I think, on the sidelines during much of the discussion, and although they didn't take over, certain concrete and compelling issues were also neglected. Most important is the question whether "everyday life" can be allowed in effect to repress "organised politics" into a separate compartment. One of the difficulties in discussing the dimensions of resistance at the conference was the absence of any information on women from the organised socialist and communist movements. Of course they were minority in the population, but their presence and activities cannot be discounted, and would provide an important framework for assessing the behaviour and choices of women who had no access to these political perspectives. It also seems important to learn more about actual class divisions among women in this period: much is written about the importance of this, but less is actually known. Similarly, what about the different experiences of women in rural and urban areas, women in office and factory work. unmarried women Catholic women? I think it's important to rescue the different specificities of the economic and social history of women in Nazi Germany, alongside the more diffuse analysis of the role of gender, or the nature of eugenicist procreation. And what were the legacies for women in the 1940s and 1950s? Were the 1930s really seen as less intolerable by comparison with the war and the occupation? Can the study of women and sexual politics in the Nazi period help us to understand the really very complex continuities and breaks in German history? These may be matters for a further conference; at any rate, they need to be addressed directly if the relevance of Nazism is to be more fully understood. 